\title{
Organic Amendments Influence Soil Water Depletion, Root Distribution, and Water Productivity of Summer Maize in the Guanzhong Plain of Northwest China
}

\author{
Li-Li Zhao ${ }^{1,2,3} \mathbb{D}$, Lu-Sheng Li ${ }^{4}$, Huan-Jie Cai ${ }^{1,2,3, *}$, Xiao-Hu Shi ${ }^{1,2,3}$ and Chao Zhang ${ }^{1,2,3}$ \\ 1 College of Water Resources and Architectural Engineering, Northwest A\&F University, Yangling 712100, \\ China; sdytdxzll@163.com (L.-L.Z.); shixiaohu2006@126.com (X.-H.S.); chaozhang13@163.com (C.Z.) \\ 2 Key Laboratory for Agricultural Soil and Water Engineering in Arid Area of Ministry of Education, \\ Northwest A\&F University, Yangling 712100, China \\ 3 Institute of Water Saving Agriculture in Arid Areas of China, Northwest A\&F University, \\ Yangling 712100, China \\ 4 School of Water Conservancy, North China University of Water Resources and Electric Power, \\ Zhengzhou 450046, China; lilusheng0715@163.com \\ * Correspondence: caihj@nwsuaf.edu.cn; Tel.: +86-29-8708-2133
}

Received: 11 October 2018; Accepted: 9 November 2018; Published: 13 November 2018

\begin{abstract}
Organic amendments improve general soil conditions and stabilize crop production, but their effects on the soil hydrothermal regime, root distribution, and their contributions to water productivity (WP) of maize have not been fully studied. A two-year field experiment was conducted to investigate the impacts of organic amendments on soil temperature, water storage depletion (SWSD), root distribution, grain yield, and the WP of summer maize (Zea mays L.) in the Guanzhong Plain of Northwest China. The control treatment (CO) applied mineral fertilizer without amendments, and the three amended treatments applied mineral fertilizer with $20 \mathrm{Mg} \mathrm{ha}^{-1}$ of wheat straw (MWS), farmyard manure (MFM), and bioorganic fertilizer (MBF), respectively. Organic amendments decreased SWSD compared to CO, and the lowest value was obtained in MBF, followed by MWS and MFM. Meanwhile, the lowest mean topsoil $(0-10 \mathrm{~cm})$ temperature was registered in MWS. Compared to CO, organic amendments generally improved the root length density (RLD) and root weight density (RWD) of maize. MBF showed the highest RLD across the whole soil profile, while MWS yielded the greatest RWD to $20 \mathrm{~cm}$ soil depth. Consequently, organic amendments increased grain yield by $9.9-40.3 \%$ and WP by $8.6-47.1 \%$ compared to CO, and the best performance was attained in MWS and MBF. We suggest that MWS and MBF can benefit the maize agriculture in semi-arid regions for higher yield, and WP through regulating soil hydrothermal conditions and improving root growth.
\end{abstract}

Keywords: soil temperature; soil water storage depletion; root growth; maize yield; semi-arid region

\section{Introduction}

The intensification of crop cultivation and livestock leads to a large increase in the production of straw and animal manure in semi-arid regions of China and elsewhere [1-3]. Recycling crop straw and animal manure by land application has been regarded as a practical method to improve general soil conditions and stabilize crop production [4-6]. However, more recently, farmers in the semi-arid regions of China have used mineral fertilizer instead of traditional organic materials due to low costs $[2,7]$. Consequently, mismanagement of crop straw and animal manure not only leads to poor soil quality and low water productivity [8,9], but also causes adverse environmental consequences, such as water and air pollution $[10,11]$. 
The Guanzhong Plain is one of the most important grain-production areas in the semi-arid region of China [8,12]. Summer maize (Zea mays L.) is a widely cultivated crop in this area, with an annual production of 3.4 billion kg of grains (Shaanxi Provincial Bureau of Statistics, http:/ / www.shaanxitj.gov.cn/). In this region, organic amendments from plant residues or livestock manure have been used, with the primary goal of improving soil water conditions and crop water productivity. For instance, $\mathrm{Yu}$ et al. [7] showed that a three-year application of ammoniated straw (ammonification of crop straw through adding urea) improved several aspects of soil quality, and significantly increased soil water storage and crop water productivity in a summer maize, winter wheat rotation. Wang et al. [13] confirmed that maize water productivity increased by $3-8 \%$ based on the improvement of grain yield in organic manured soils over four years, although soil water content decreased in the 50-150 cm soil layer. However, Yang et al. [1] reported that 8-year manure amendments increased soil water content in the $0-10 \mathrm{~cm}$ soil layer compared with the sole application of mineral fertilizer, while it depressed the crop yield of the wheat-soybean cropping system. The discrepancy in observed effects may be due to the variations in environmental duration, cropping system, and the characteristics of applied organic materials. The differences in the compositions of various organic amendments have different effects on soil water status and crop water productivity by the changes in soil's physical, chemical, and biological functions $[5,14,15]$. Therefore, it is essential to assess the effects of various organic amendments on soil water conditions and crop water productivity for adjusting the optimum organic amendment practices to local conditions.

Roots are important organs for plant growth and mediators of associations between the effects of organic amendments on soils, shoots, and grain yields [16]. Root growth is crucial in optimizing crop yield and water productivity in semi-arid regions [17,18]. Previous studies have provided important insights into organic amendments in terms of regulating plant root growth. The nutrients released from decomposing organic materials play a key role in the penetration and establishment of plant roots [19-21], which helps the crop to utilize water and nutrients from deeper layers and to maintain high water productivity under soil water stress conditions [18,22]. The type of applied organic amendments is also an important factor [14,23]. For example, Gaiotti et al. [23] found that adding compost from vine-pruning waste strongly stimulated vines' root development, while compost derived from cattle manure waste had no significant effect on the root systems. However, the relationships between root distribution and both yield and water productivity remain key issues of discussion.

This study aims to evaluate the effects of organic amendments on soil hydrothermal conditions and root growth to ensure the stable increase in grain yield and water productivity of summer maize. For this purpose, a two-year study was undertaken in the Guanzhong Plain of Northwest China to evaluate the effects of three common organic amendments (wheat straw, farmyard manure, and bioorganic fertilizer) on soil temperature, soil water storage depletion, root growth, and their contributions to grain yield and water productivity of summer maize. We hypothesized that: (i) organic amendments could alter soil hydrothermal conditions and root growth, and therefore favor yield and water productivity (WP) increase; (ii) these organic amendments-induced effects would be variable due to the differences in the types of added organic materials.

\section{Materials and Methods}

\subsection{Study Site}

A field experiment was conducted through two consecutive summer maize-growing seasons (June-October) from 2014 to 2015 in a maize-wheat cropping system. The experimental site is located at the Key Laboratory of Agricultural Soil and Water Engineering in Arid Area ( $34^{\circ} 17^{\prime} \mathrm{N}, 108^{\circ} 04^{\prime} \mathrm{E}$, $506 \mathrm{~m}$ a.s.l.) in the Guanzhong Plain, a semi-arid region of northwest China. This region has a semi-arid to sub-humid climate, with $632 \mathrm{~mm}$ annual rainfall and $13{ }^{\circ} \mathrm{C}$ mean annual temperature. The soil at the site is classified as Eum-Orthic Anthrosols [8] with basic physicochemical properties presented in Table 1 (sampled on 9 June 2014). 
Table 1. Initial characteristics of the soil sampled in different soil layers in the experimental fields in June 2014.

\begin{tabular}{|c|c|c|c|}
\hline \multirow{2}{*}{ Parameters } & \multicolumn{3}{|c|}{ Depth (cm) } \\
\hline & 0-20 & $20-60$ & $60-100$ \\
\hline Texture (international system) & Clay loam & Silty clay loam & Silty clay loam \\
\hline Sand $(0.02 \sim 2 \mathrm{~mm})\left({\left.\mathrm{g} 100 \mathrm{~g}^{-1}\right)}^{\prime}\right.$ & 37.44 & 29.44 & 24.11 \\
\hline Silt $(0.002 \sim 0.02 \mathrm{~mm})\left(\mathrm{g} 100 \mathrm{~g}^{-1}\right)$ & 44.01 & 48.48 & 54.52 \\
\hline Clay $(<0.002 \mathrm{~mm})\left(\mathrm{g} 100 \mathrm{~g}^{-1}\right)$ & 18.59 & 23.10 & 21.37 \\
\hline Bulk density $\left(\mathrm{g} \mathrm{cm}^{-3}\right)$ & 1.38 & 1.58 & 1.39 \\
\hline Field capacity $\left(\mathrm{cm}^{3} \mathrm{~cm}^{-3}\right)$ & 0.33 & 0.31 & 0.30 \\
\hline Organic matter $\left(\mathrm{g} \mathrm{kg}^{-1}\right)$ & 14.57 & 10.03 & 8.04 \\
\hline Total N $\left(\mathrm{g} \mathrm{kg}^{-1}\right)$ & 0.92 & 0.71 & 0.66 \\
\hline Total $\mathrm{P}_{2} \mathrm{O}_{5}\left(\mathrm{~g} \mathrm{~kg}^{-1}\right)$ & 0.58 & 0.47 & 0.38 \\
\hline Total $\mathrm{K}_{2} \mathrm{O}\left(\mathrm{g} \mathrm{kg}^{-1}\right)$ & 10.12 & 9.47 & 8.67 \\
\hline Soil pH & 8.57 & 8.53 & 8.36 \\
\hline
\end{tabular}

\subsection{Treatments and Crop Management}

The experiment was conducted in a randomized complete block design with four treatments replicated three times in $7.5 \mathrm{~m} \times 4.0 \mathrm{~m}$ plots (fixed plot test). Four treatments consisted of a control (CO) with additions of mineral fertilizer $\left(\mathrm{N}: \mathrm{P}=170: 170 \mathrm{~kg} \mathrm{ha}^{-1}\right)$ without organic matter, and the same doses of mineral fertilizer along with wheat straw (MWS), farmyard manure (MFM), and bioorganic fertilizer (MBF). Three types of organic materials were applied in the field at the rate of $20 \mathrm{Mg} \mathrm{ha}^{-1}$ (dry weight). The wheat straw was cut into $2 \mathrm{~cm}$ segments. The farmyard manure used was from a mixture of $80 \%$ decomposed sheep manure and $20 \%$ soil by weight, following the production method of local farmers. The bioorganic fertilizer consisted of farmyard manure and microbial agent (60 $\mathrm{kg} \mathrm{ha}^{-1}, 2 \times 10^{8} \mathrm{cfu} \mathrm{g}^{-1}$ living bacteria, supplied by Sino Green Agri-Biotech Company, Beijing, China). Basic physico-chemical properties of the organic materials are listed in Table 2.

Table 2. Physico-chemical characteristics of the applied organic materials.

\begin{tabular}{cccccc}
\hline Material & $\begin{array}{c}\text { Organic Carbon } \\
\left(\mathbf{g ~ k g}^{-\mathbf{1}} \mathbf{)}\right.\end{array}$ & $\begin{array}{c}\text { Total N } \\
\left(\mathbf{g ~ k g}^{-\mathbf{1}}\right)\end{array}$ & $\begin{array}{c}\text { Total P } \\
\left(\mathbf{g ~ k g}^{-\mathbf{1}}\right)\end{array}$ & $\begin{array}{c}\text { Total K } \\
\left(\mathbf{g ~ k g}^{-\mathbf{1}}\right)\end{array}$ & $\begin{array}{c}\text { Dry Bulk Density } \\
\left(\mathbf{g ~ c m}^{-3}\right)\end{array}$ \\
\hline Wheat straw & $432.44 \mathrm{a}$ & $10.84 \mathrm{~b}$ & $1.65 \mathrm{~b}$ & $9.71 \mathrm{a}$ & $0.074 \mathrm{c}$ \\
Farmyard manure & $190.30 \mathrm{~b}$ & $11.63 \mathrm{ab}$ & $3.02 \mathrm{a}$ & $6.49 \mathrm{~b}$ & $0.474 \mathrm{a}$ \\
Bioorganic fertilizer & $184.19 \mathrm{~b}$ & $12.98 \mathrm{a}$ & $3.19 \mathrm{a}$ & $6.27 \mathrm{~b}$ & $0.325 \mathrm{~b}$ \\
\hline
\end{tabular}

Note: Different letters in the same column indicate significant differences at the $5 \%$ probability level.

Summer maize (Zhengdan 958) was planted manually on 18 June 2014 and 15 June 2015, and was harvested manually on 15 October 2014 and 13 October 2015. The plant population was approximately 51,892 plant ha ${ }^{-1}$ with a row spacing of $60 \mathrm{~cm}$ and a plant spacing of $30 \mathrm{~cm}$. Maize was fertilized with a uniform dose of $170 \mathrm{~kg} \mathrm{~N} \mathrm{ha}^{-1}$ and $170 \mathrm{~kg} \mathrm{P}_{2} \mathrm{O}_{5} \mathrm{ha}^{-1}$ in the form of urea $(46 \% \mathrm{~N})$ and diammonium phosphate $\left(18 \% \mathrm{~N}, 46 \% \mathrm{P}_{2} \mathrm{O}_{5}\right) .60 \%$ of the mineral fertilizer was applied as a basal fertilizer, and the remaining $40 \%$ was top-dressed at the 12-leaf stage. Before planting, $60 \%$ of mineral fertilizer and all of the organic materials were mixed up with the soils by a moldboard plow to a depth of around $25 \mathrm{~cm}$ as per the treatment. Organic insecticide $\left(15 \mathrm{~kg} \mathrm{ha}^{-1}\right)$ was also incorporated into the soil to control pest insects before sowing. Hand weeding was performed at the 6-leaf stage and 12-leaf stage during the maize growing seasons. All experimental plots were irrigated using flood irrigation with the same amount of underground water $(75 \mathrm{~mm})$ at 42 days after sowing (DAS). Crop residues were manually removed after harvest. 


\subsection{Sampling and Measurements}

Rectangular geothermometers (Jingda Thermal Instruments, Hengshui, China) were installed at depths of $0,5,10$ and $20 \mathrm{~cm}$ in the middle of each plot. The soil temperature was recorded at 10-day intervals after sowing, and the values recorded at 8:00, 14:00 and 20:00 were averaged and treated as mean diurnal soil temperature.

Soil water content was measured gravimetrically at $10 \mathrm{~cm}$ intervals, down to $100 \mathrm{~cm}$ depth, at the times of 0, 40, 60, 80, 100 and 120 DAS in 2014 and 2015. Seasonal soil water storage depletion (SWSD) and evapotranspiration (ET) was determined according to the following equations [7,13]:

$$
\begin{gathered}
S W S=\sum S W C_{i} \times S B D_{i} \times S D_{i}, \\
S W S D_{j \sim j+1}=S W S_{j}-S W S_{j+1}, \\
\mathrm{ET}=P+I+S W S D,
\end{gathered}
$$

where SWS is the soil water storage in the $0-100 \mathrm{~cm}$ soil layer $(\mathrm{mm}), S W C$ is soil gravimetric water content $\left(\mathrm{g} \mathrm{g}^{-1}\right), S B D$ is soil bulk density $\left(\mathrm{g} \mathrm{cm}^{-3}\right), S D$ is soil depth $(\mathrm{cm}), S W S D_{j \sim j+1}$ is the change in SWS form stage $j\left(S W S_{j}\right)$ to stage $j+1\left(S W S_{j+1}\right)(\mathrm{mm})$, ET is the evapotranspiration from the sowing to maturity stage $(\mathrm{mm}), P$ is rainfall $(\mathrm{mm})$, and $I$ is irrigation $(\mathrm{mm})$. Water losses to runoff and deep drainage were assumed to be negligible as no heavy rains or irrigations occurred during the maize growing seasons in this flat experiment field.

On five sampling occasions during the growing seasons (40, 60, 80, 100, and 120 DAS), soil-root columns were taken at $10 \mathrm{~cm}$ increments to a depth of $100 \mathrm{~cm}$ using a root auger $(7.3 \mathrm{~cm}$ internal diameter). The columns were randomly collected at three positions located at the planting spot $(0 \mathrm{~cm})$, $15 \mathrm{~cm}$ to one side $(-15 \mathrm{~cm})$ and $15 \mathrm{~cm}$ to the opposite side $(+15 \mathrm{~cm})$ of three tagged plants in each plot, and the mean value was used. Roots were gently washed by swirling water through a $400 \mu \mathrm{m}$ sieve to remove the surrounding soil. Washed root samples (live root) were scanned with a HP scanjet 8200 scanner and analyzed using Delta-T Scan image analysis software (Delta-T Devices Company, Cambridge, UK) to determine root length. These root samples were then oven-dried at $75{ }^{\circ} \mathrm{C}$ to constant weight, and root dry weight was recorded. The root length $(\mathrm{cm})$ and root weight $(\mathrm{g})$ were divided by the soil-root core volume $\left(\mathrm{cm}^{3}\right)$ to calculate root length density (RLD, $\mathrm{cm} \mathrm{cm}^{-3}$ ) and root weight density ( $R W D, \mathrm{~g} \mathrm{~cm}^{-3}$ ), respectively.

At maturity, the two central rows were manually harvested to determine the aboveground biomass and grain yields of summer maize (standardized to $12 \%$ moisture). Yield components, including numbers of kernel spike ${ }^{-1}$, grain weight spike ${ }^{-1}$ and 100-grain weight were also derived from measurements on these harvested plants. Water productivity (WP, $\mathrm{kg} \mathrm{ha}^{-1} \mathrm{~mm}^{-1}$ ) was calculated by dividing the grain yield $\left(\mathrm{kg} \mathrm{ha}^{-1}\right)$ by ET $(\mathrm{mm})$.

\subsection{Statistical Analysis}

All treatment effects were subjected to univariate analysis using the SPSS 17.0 software (SPSS, Inc., Chicago, IL, USA). The treatment effects at different time intervals were tested by the analysis of variances (ANOVA). Significant differences among treatments were separated using least significant difference (LSD) tests at $p<0.05$. The influence of all treatments on soil hydrothermal, maize root, and yield parameters and their relationships among each other were analyzed by the principal component analysis (PCA). The RLD and RWD distributions were visualized as two-dimensional graphs generated using the SURFER 8.0 software package (Golden Software, LLC, Golden, CO, USA). 


\section{Results}

\subsection{Weather Conditions during the Study Period}

The precipitation during the maize growing season was $381.3 \mathrm{~mm}$ in 2014 and $278.2 \mathrm{~mm}$ in 2015, and this accounted for $56.3 \%$ and $46.5 \%$ of the annual precipitation, respectively (Figure 1). A large proportion of precipitation occurred in August and September, compared with the other months of the vegetative season over the two years. Based on a 30-year (1986-2015) average precipitation (322.1 mm) during the maize-growing season, 2014 and 2015 can be considered as a wet year and a normal year, respectively. The trends of average daily temperature were similar during the two maize-growing seasons. The highest daily mean temperature was $32.3^{\circ} \mathrm{C}$ and $31.3^{\circ} \mathrm{C}$ in 2014 and 2015 , respectively, in both cases in July.

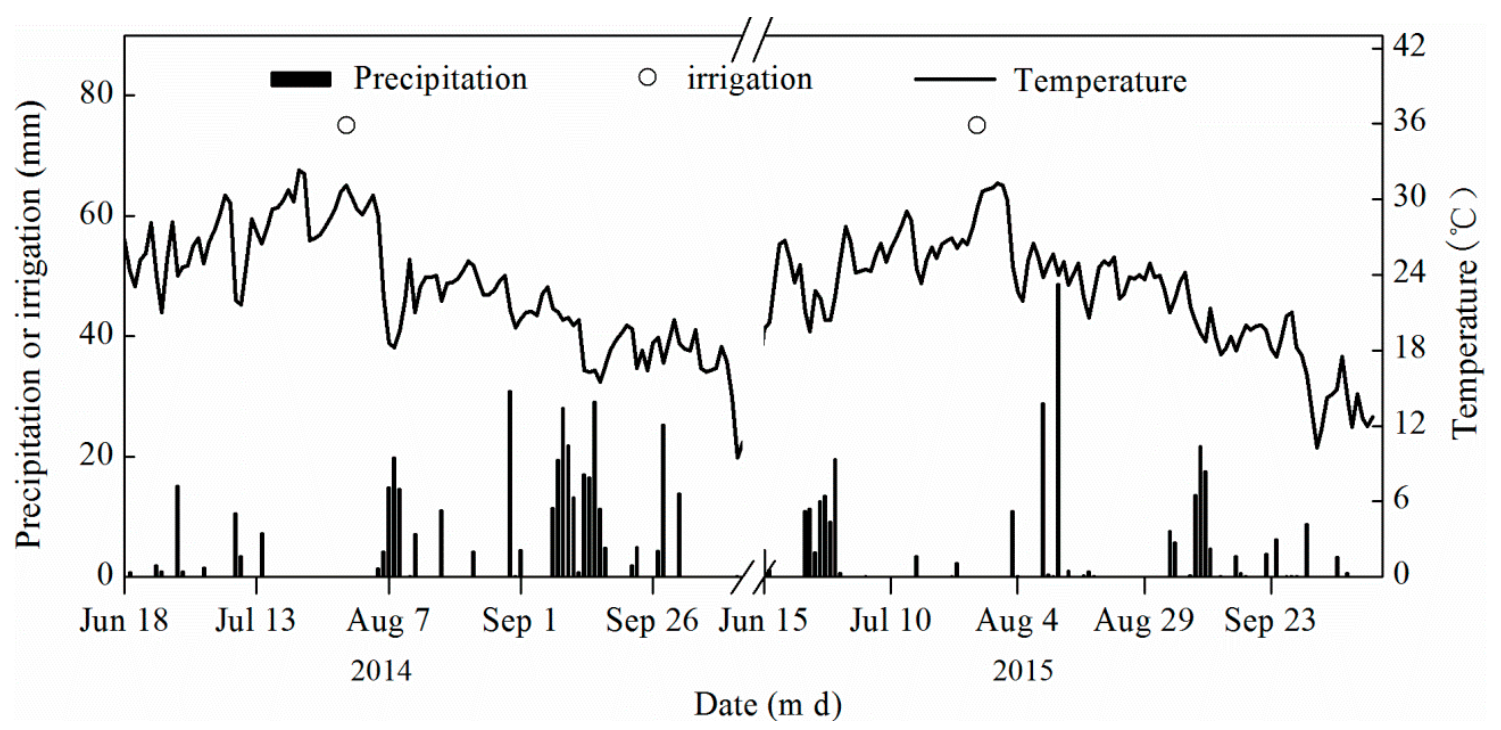

Figure 1. Daily rainfall, irrigation, and average daily temperature recorded during the summer maize growing seasons in 2014 and 2015.

\subsection{Soil Temperature}

The soil temperature trends were similar in the 2014 and 2015 growth periods (Table 3), as shown by the temporal and spatial variations in daily mean soil temperature under all treatments presented in Figure 2. Soil temperature at 0,5,10 and $20 \mathrm{~cm}$ depths followed a downward quadratic curve from sowing to maturation across all treatments, peaking at 40 DAS (July), following the similar pattern to the observed changes in air temperatures (Figure 1). Generally, organic amendments resulted in significant differences in the mean soil temperature at $0-10 \mathrm{~cm}$ depth, where the significantly $(p<0.05)$ lowest mean soil temperature was registered in MWS among all treatments. Nonetheless, the soil temperature remained almost invariable among the treatments at $20 \mathrm{~cm}$ depth, because it was weakly affected by solar radiation energy in this layer.

The effect of organic amendments on soil temperature was large at the early growth stages of maize (0-40 DAS), when the daily mean soil temperatures in MWS at 0,5, and $10 \mathrm{~cm}$ depth were $1.3,3.2$, and $1.9^{\circ} \mathrm{C}$ lower than those in $\mathrm{CO}$, respectively $(p<0.05)$ (Figure 2$)$. Conversely, the daily mean soil temperatures in MFM and MBF at $0 \mathrm{~cm}$ depth were 4.0 and $3.7^{\circ} \mathrm{C}$ higher than those in $\mathrm{CO}$, respectively $(p<0.05)$. This was probably due to the dark color of the farmyard manure and bioorganic fertilizer. The dark color organic materials showed high absorptivity and low reflectivity. However, at the middle growth stages (40-100 DAS), the full establishment of maize canopy and the spell of hot weather led to a minimal impact on soil temperature with organic amendments when compared to CO. At the later growth stages (100-120 DAS), organic amendments increased $(p<0.05)$ the daily mean soil 
temperatures at $0-10 \mathrm{~cm}$ depth by $0.6-1.6^{\circ} \mathrm{C}$ compared to $\mathrm{CO}$, due to the improvement of topsoil heat storage with the consecutive decomposition of organic materials, especially in cool conditions.

Table 3. Significance of the effects of organic amendment treatments, year, and their interactions on the soil and crop parameters.

\begin{tabular}{cccccc}
\hline Parameters & \multirow{2}{*}{$\begin{array}{c}\text { Tests of } \\
\text { Normality }\end{array}$} & $\begin{array}{c}\text { Tests of Homogeneity } \\
\text { of Variances }\end{array}$ & \multicolumn{3}{c}{ ANOVA } \\
\cline { 4 - 6 } & & $\mathrm{ns}$ & $\mathrm{ns}$ & $\mathbf{Y} \times \mathbf{T}$ \\
\hline Soil temperature & $\mathrm{ns}$ & $\mathrm{ns}$ & $\mathrm{ns}$ & $*$ & $\mathrm{~ns}$ \\
Soil water storage depletion & $\mathrm{ns}$ & $\mathrm{ns}$ & $\mathrm{ns}$ & $* *$ & $*$ \\
Root length density & $\mathrm{ns}$ & $\mathrm{ns}$ & $\mathrm{ns}$ & $* *$ & $*$ \\
Root weight density & $\mathrm{ns}$ & $\mathrm{ns}$ & $* *$ & $* *$ & $* *$ \\
Grain yield & $\mathrm{ns}$ & $\mathrm{ns}$ & $* *$ & $* *$ & $* *$ \\
Water productivity & & &
\end{tabular}

Note: $Y$, year; $T$, treatment; $n s$, not significant. ${ }^{*}$, significant differences at the $5 \%$ probability level; ${ }^{* *}$, significant differences at the $1 \%$ probability level.

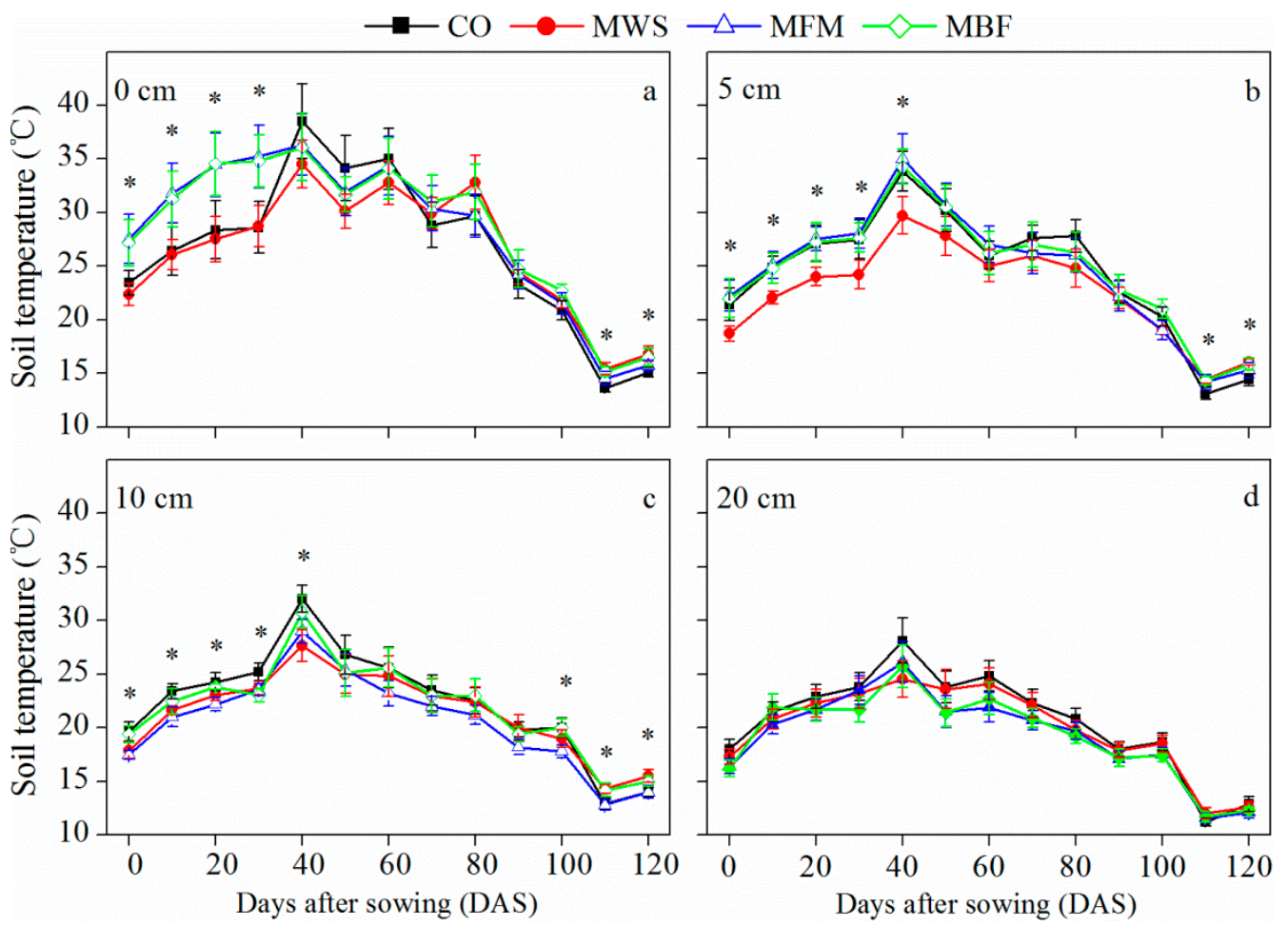

Figure 2. Effects of the treatments on average soil temperatures at indicated depths during the summer maize-growing seasons in 2014 and 2015. CO, mineral fertilizer without organic amendments; MWS, mineral fertilizer with wheat straw; MFM, mineral fertilizer with farmyard manure; MBF, mineral fertilizer with bioorganic fertilizer. ${ }^{*}, p<0.05$.

\subsection{Soil Water Depletion}

As shown in Figure 3, organic amendments generally reduced the ET in the first $100 \mathrm{~cm}$ of the soil profile from sowing to harvesting over the two maize-growing seasons. More specifically, MBF significantly decreased the SWSD in the $0-100 \mathrm{~cm}$ soil layer by 18.3 and $29.5 \mathrm{~mm}$ compared to CO in 2014 and $2015(p<0.05)$, respectively. Meanwhile, MWS and MFM also decreased the SWSD by 0.8 and $4.1 \mathrm{~mm}$ in $2014(p>0.05)$ and 24.6 and $15.3 \mathrm{~mm}$ in $2015(p<0.05)$ compared to CO, respectively. Notably, the middle layer $(20-60 \mathrm{~cm})$ contributed to the major variations of the SWSD from the entire profile. 


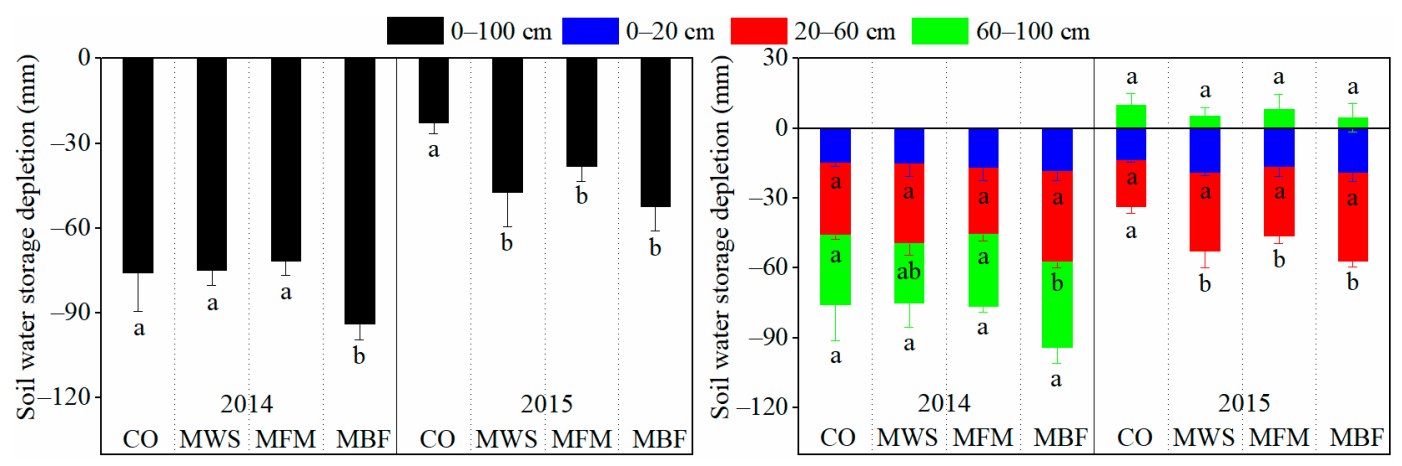

Figure 3. Total soil water storage depletion (SWSD) under indicated treatments from different soil layers in the 2014 and 2015 growing seasons. The abbreviations of the treatment names are the same as those described in Figure 2. Means of the SWSD within the same soil layer sharing the different lowercase letters are significantly different at $p<0.05$.

There were clear variations in the SWSD across treatments at different growth stages (Figure 4), which depended on the intensity and distribution of rainfall and evapotranspiration. At the early growth stages, the maize plants were small and water depletion mainly resulted from soil evaporation. MWS and MBF reduced the SWSD compared to CO $(p<0.05)$ by decreasing soil evaporation loss in 2014, while these between-treatments differences were negligible in 2015. The reason for this phenomenon may be related to more replenished rainfall in $2015(93.6 \mathrm{~mm})$ than in $2014(42.7 \mathrm{~mm})$ during this stage. However, crop transpiration was the major pathway for water depletion due to the fast development of the maize canopy. This was especially true in MWS, which resulted in a significantly $(p<0.05)$ higher SWSD due to the best maize growth (Table 4$)$ at 40-80 DAS over the two-year period. At 80-120 DAS, there was a desirable amount of rainfall in 2014 (224.6 mm) compared to the less rainfall $(91.3 \mathrm{~mm})$ in 2015. Therefore, there were no differences in the SWSD among the treatments in 2014, while MWS, MFM, and MBF resulted in significantly lower SWSD compared to $\mathrm{CO}$ in 2015 during this period $(p<0.05)$. The result clearly implied that the positive effects of organic amendments on SWSD mainly occurred in the early/middle-late growth stages of the dry spell.

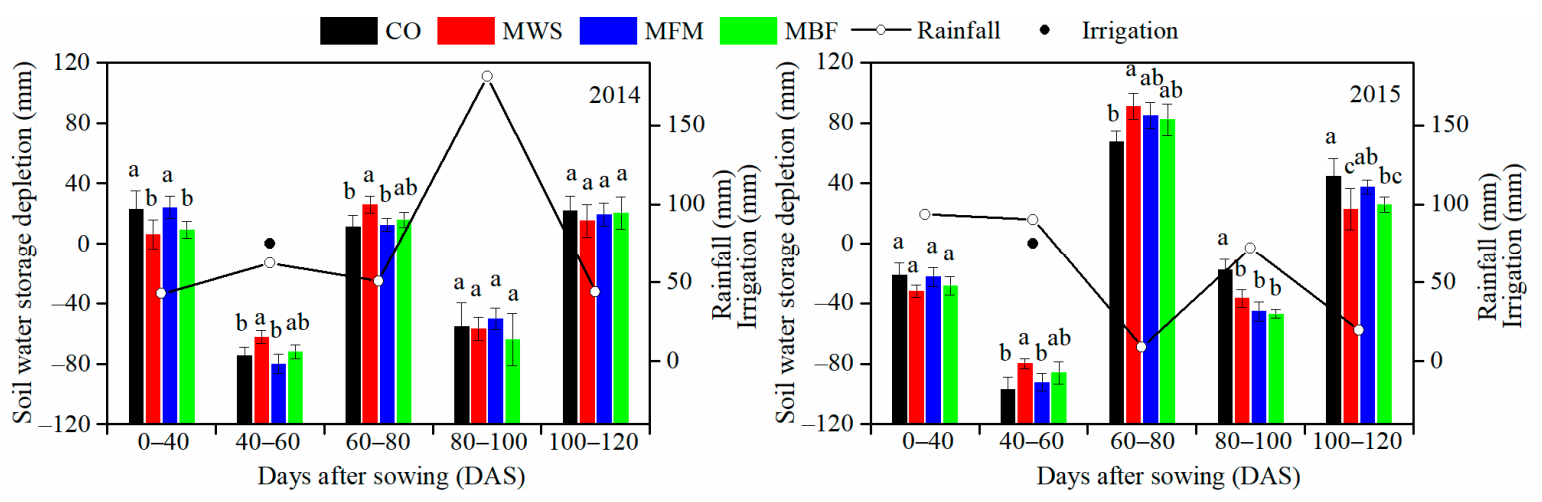

Figure 4. The soil water storage depletion (SWSD) in the $0-100 \mathrm{~cm}$ layers under indicated treatments during the different maize growth stages in 2014 and 2015. The abbreviations of the treatment names are the same as those described in Figure 2. Means of the SWSD within the same growth stage sharing the different lowercase letters are significantly different at $p<0.05$. 
Table 4. Maize grain yield, yield components, aboveground biomass, evapotranspiration (ET), and water productivity (WP) under indicated treatments in the 2014 and 2015 growing seasons.

\begin{tabular}{|c|c|c|c|c|c|c|c|c|}
\hline Year & Treatments & $\begin{array}{l}\text { Kernels } \\
\text { Spike }^{-1}\end{array}$ & $\begin{array}{l}\text { Grain Weight } \\
\text { Spike }^{-1} \text { (g) }\end{array}$ & $\begin{array}{l}\text { 100-Grain } \\
\text { Weight (g) }\end{array}$ & $\begin{array}{c}\text { Grain Yield } \\
\left(\mathrm{kg} \mathrm{ha}^{-1}\right)\end{array}$ & $\begin{array}{c}\text { Aboveground } \\
\text { Biomass }\left(\mathrm{kg} \mathrm{ha}^{-1}\right)\end{array}$ & ET (mm) & $\begin{array}{c}\text { WP } \\
\left(\mathrm{kg} \mathrm{ha}^{-1} \mathrm{~mm}^{-1}\right)\end{array}$ \\
\hline \multirow{3}{*}{2014} & $\mathrm{CO}$ & $418.4 \mathrm{c}$ & $106.4 \mathrm{c}$ & $24.9 \mathrm{c}$ & $5626.4 \mathrm{~d}$ & $11013.8 b$ & $379.7 \mathrm{a}$ & $14.8 \mathrm{c}$ \\
\hline & MWS & $451.2 \mathrm{~b}$ & $136.4 \mathrm{a}$ & $30.7 \mathrm{a}$ & $7895.0 \mathrm{a}$ & $13582.1 \mathrm{a}$ & $380.5 \mathrm{a}$ & $20.8 \mathrm{a}$ \\
\hline & $\mathrm{MBF}$ & 477.6a & $117.3 b$ & $28.6 b$ & $7122.1 b$ & $12818.0 \mathrm{a}$ & $361.4 \mathrm{~b}$ & $19.7 \mathrm{a}$ \\
\hline \multirow{2}{*}{2015} & $\mathrm{CO}$ & $424.1 \mathrm{c}$ & $129.1 b$ & $29.8 \mathrm{c}$ & $7204.8 \mathrm{c}$ & $13434.6 \mathrm{~b}$ & $336.1 \mathrm{a}$ & $21.4 \mathrm{c}$ \\
\hline & MWS & $489.4 \mathrm{a}$ & $150.4 a$ & $31.8 \mathrm{a}$ & $9376.1 \mathrm{a}$ & $16631.3 \mathrm{a}$ & $310.7 \mathrm{~b}$ & $30.2 a$ \\
\hline
\end{tabular}

Note: The abbreviations of the treatment names are the same as those described in Figure 2. Different lowercase letters within columns in each year indicate significant differences at the $5 \%$ probability level.

\subsection{Maize Root Systems}

\subsubsection{Vertical Distribution of RLD and RWD}

There was no significant difference between the root densities at maturity in 2014 and 2015 (Table 3). The vertical distributions of RLD and RWD shown in Figures 5 and 6 were the average results over the two years.
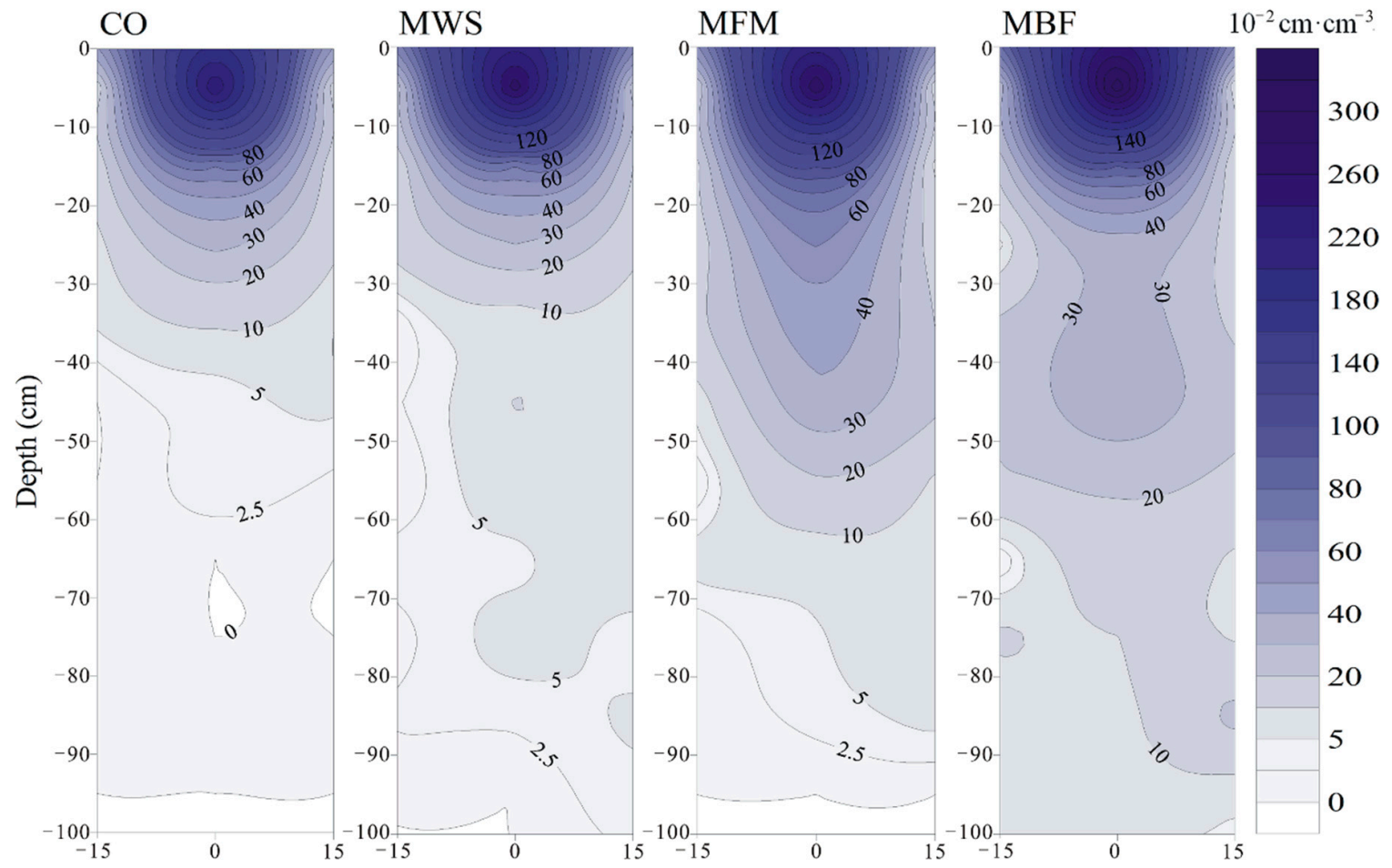

Horizontal distance $(\mathrm{cm})$ Horizontal distance $(\mathrm{cm})$ Horizontal distance $(\mathrm{cm})$ Horizontal distance $(\mathrm{cm})$

Figure 5. Two-dimensional distributions of the mean root-length density in the $0-100 \mathrm{~cm}$ layer under indicated treatments at maturity averaged over two years. The abbreviations of the treatment names are the same as those described in Figure 2.

The RLD in MBF was the highest among all treatments across all the soil profiles, and the ratio of the RLD between MBF and CO increased with increasing soil depth, which was 1.3, 3.1, and 20.5 times in the 0-20, 20-60, and 60-100 cm soil layers, respectively $(p<0.05)$ (Figure 5). A similar trend was observed in MFM, with 2.0 and 7.2 times higher RLD than that in CO at 20-60 cm and $60-100 \mathrm{~cm}$ depth, respectively $(p<0.05)$. However, this increase was only observed at $60-100 \mathrm{~cm}$ depth in MWS, where the RLD was 7.2 times higher in MWS than in CO $(p<0.05)$. 


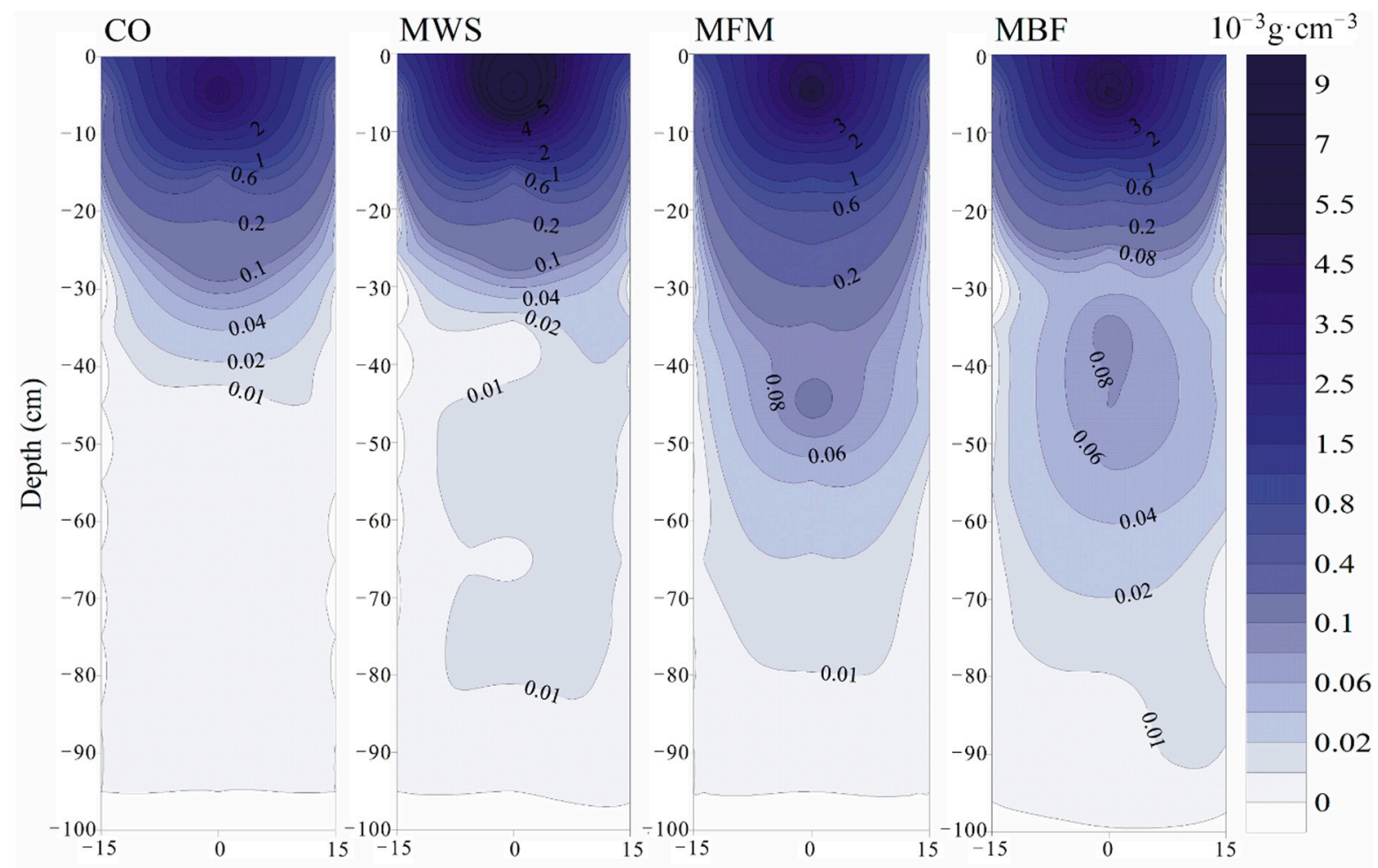

Horizontal distance $(\mathrm{cm})$ Horizontal distance $(\mathrm{cm})$ Horizontal distance $(\mathrm{cm})$ Horizontal distance $(\mathrm{cm})$

Figure 6. Two-dimensional distributions of the mean root-weight density in the $0-100 \mathrm{~cm}$ layer under indicated treatments at maturity averaged over two years. The abbreviations of the treatment names are the same as those described in Figure 2.

The RWD followed similar patterns to the observed RLD trends across the profile, except for the 0-20 cm depth, where the highest value of RWD occurred in MWS followed by MFM and MBF, and CO yielded the lowest value $(p<0.05)$ (Figure 6). At 20-60 cm depth, the RWD in MFM and MBF were significantly $(p<0.05)$ higher by 1.7 and 0.5 times than that in CO, respectively. At $60-100 \mathrm{~cm}$ depth, the RWD in MWS, MFM, and MBF were significantly $(p<0.05)$ higher by $4.4,4.2$, and 7.9 times that in $\mathrm{CO}$, respectively. As expected, organic amendments improved the ability of the maize root system to grow down and stretch into the deep layer compared to $\mathrm{CO}$, which was especially true in MBF.

\subsubsection{Changes in RLD and RWD with Crop Development}

Generally, different organic amendments had a significant impact on the root densities of maize at various growth stages in 2015 (Figure 7). MBF and MFM had significantly $(p<0.05)$ greater mean RLD compared to MWS and CO. This was especially true at 80-120 DAS, when the RLD in MFM and MBF were $10.8-65.1 \%$ significantly $(p<0.05)$ higher compared to MWS and CO (Figure 7a). Additionally, MWS also had positive changes in RLD compared to $\mathrm{CO}$, but these changes were only significant $(p<0.05)$ at 40 DAS $(35.2 \%)$.

There were notable between-treatment differences in RWD at 40 DAS and 80-120 DAS, when the mean RWD in MWS, MFM, and MBF was 106, 83.2, and 47.6\% higher than that in CO, respectively $(p<0.05)$ (Figure 7b). Moreover, the RWD in MWS was 31.7-60.5\% greater than that in other treatments at 40 DAS $(p<0.05)$, and these differences became more significant at 100 and 120 DAS. 

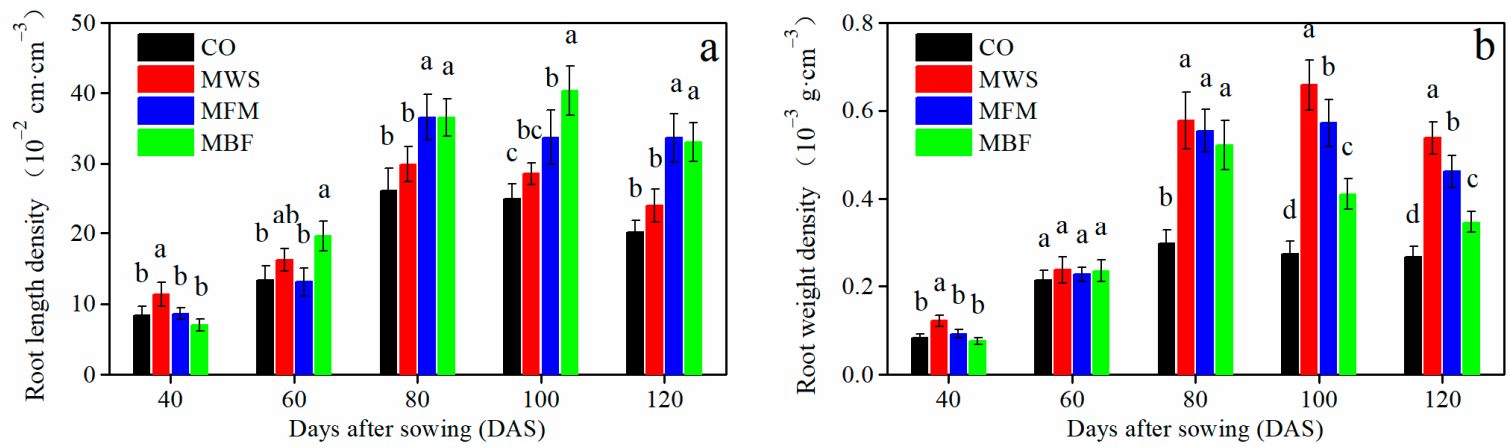

Figure 7. The root-length density (RLD) and root-weight density (RWD) under indicated treatments on different days after sowing during the 2015 growing season. The abbreviations of the treatment names are the same as those described in Figure 2. Means of the RLD or RWD within the same days after sowing sharing the different lowercase letters are significantly different at $p<0.05$.

\subsection{Maize Grain Yield, Yield Components, and WP}

The grain yield, yield components, and WP of maize were considerably $(p<0.05)$ affected by the organic amendments, and the values were significantly $(p<0.05)$ higher in 2015 than in 2014 (Tables 3 and 4). Over the two years, organic treatments significantly $(p<0.05)$ increased grain yield (9.9-40.3\%) and WP (8.6-47.1\%) compared to CO, and MWS and MBF generally had the highest values. Similarly, MWS and MBF also had significantly $(p<0.05)$ higher aboveground biomass by $10.5-23.8 \%$ compared to CO and MFM. In addition, kernel spike ${ }^{-1}$, grain weight spike ${ }^{-1}$ and 100-grain weight in MWS and MBF were significantly $(p<0.05)$ higher compared to CO over the two years, while MFM only had significantly $(p<0.05)$ higher values relative to CO in 2015.

\subsection{Impact Factors for Yield and WP}

The PCA of all treatments, soil hydrothermal characteristics, and crop growth parameters indicated that the first two principal components explained $70.4 \%$ of the experimental variance (Figure 8). Direction and size of the line revealed that a number of yield-related parameters were mainly associated with MBF and MWS treatments. However, these yield parameters, such as grain yield, WP, aboveground biomass, kernel spike ${ }^{-1}$, grain weight spike ${ }^{-1}$, and 100-grain weight were negatively related to MFM and CO treatments. Among the soil hydrothermal variables, soil temperature at 100-120 DAS was positively linked to crop yield and WP. The SWSD at 0-40 and 80-120 DAS were negatively correlated with yield-related parameters, while the SWSD at 40-80 DAS was positively related with the aforementioned parameters. Additionally, total SWSD from sowing to harvesting at 20-60 $\mathrm{cm}$ depth was negatively associated with yield-related parameters.

Among the crop root parameters, the RLD and RWD at 80-120 DAS were significantly related to grain yield and WP, and significant correlations were also detected between RWD at 60 DAS and both grain yield and WP (Table 5). The results indicated that root densities significantly affected grain yield and WP from the middle of the growing seasons onwards. With regard to soil depth, both RLD and RWD in the 0-20 and 60-100 cm layers at maturity provided a great contribution to crop yield and WP (Figure 8). 


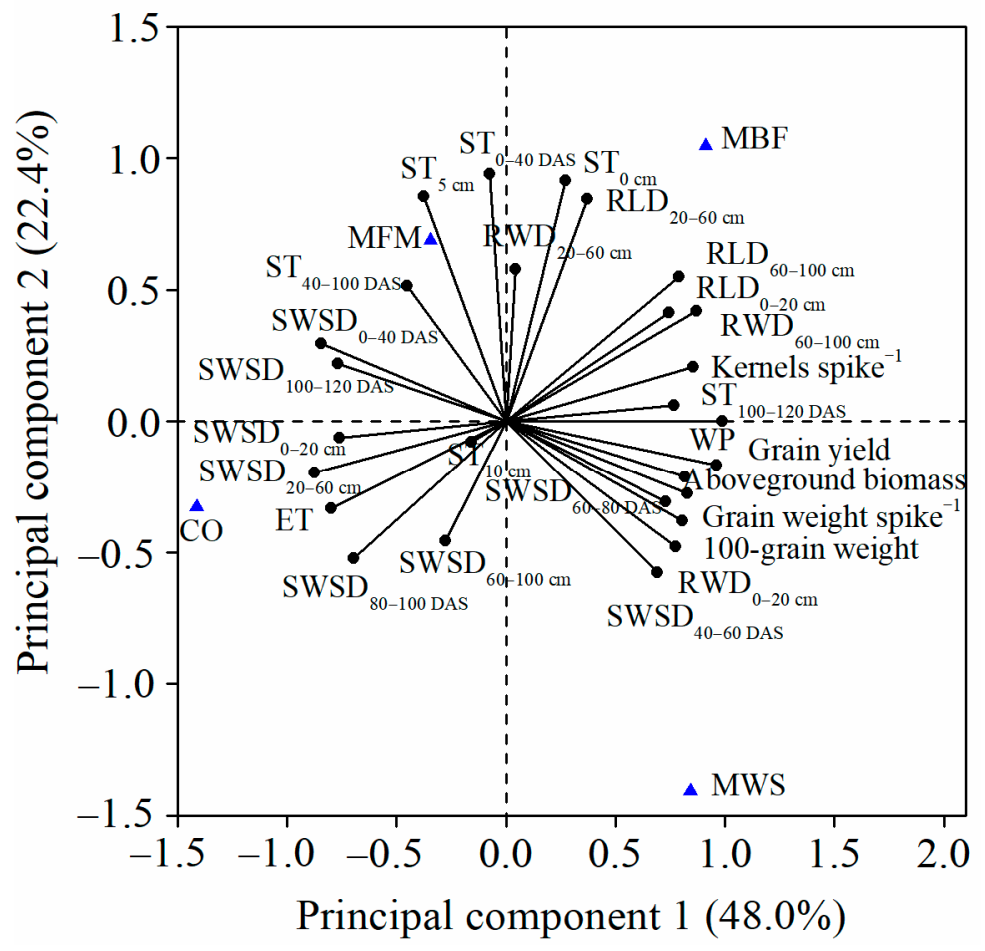

Figure 8. Principal component analysis (PCA) for various treatments as a function of soil and crop parameters. Treatment abbreviations are the same as those described in Figure 2. ST $0-40$ DAS, ST $_{40-100 ~ D A S}$, and ST $100-120$ DAS: soil temperature at 0-40, 40-100, and 100-120 DAS in the 0-10 cm soil layer; $\mathrm{ST}_{0 \mathrm{~cm}}, \mathrm{ST}_{5 \mathrm{~cm}}$, and $\mathrm{ST}_{10 \mathrm{~cm}}$ : soil temperature at 0,5 , and $10 \mathrm{~cm}$ depth during the whole maize growth seasons; SWSD $_{0-40}$ DAS-SWSD $100-120$ DAS: soil water storage depletion at 0-40, 40-60, 60-80, 80-100, and 100-120 DAS; SWSD $0-20 \mathrm{~cm}$, SWSD $_{20-60 \mathrm{~cm}}$, and SWSD $60-100 \mathrm{~cm}$ : soil water storage depletion from sowing to harvest at 0-20, 20-60, and 60-100 cm depths. $R_{L D}-20 \mathrm{~cm}, \mathrm{RLD}_{20-60 \mathrm{~cm}}$ and $\mathrm{RLD}_{60-100 \mathrm{~cm}}$ : root length density at 0-20, 20-60, and 60-100 cm depths at maturity; $\mathrm{RWD}_{0-20 \mathrm{~cm}}$ RWD $20-60 \mathrm{~cm}$, and $\mathrm{RWD}_{60-100 \mathrm{~cm}}$ : root weight density at 0-20, 20-60, and 60-100 cm depths at maturity; ET: evapotranspiration; WP: water productivity.

Table 5. Correlations between both grain yield and WP and root densities measured at different days after sowing of summer maize in various organic amendment management systems.

\begin{tabular}{ccccccc}
\hline \multirow{2}{*}{\multicolumn{2}{c}{ Root Densities }} & \multicolumn{5}{c}{ Days after Sowing (DAS) } \\
\cline { 3 - 7 } & & $\mathbf{4 0}$ & $\mathbf{6 0}$ & $\mathbf{8 0}$ & $\mathbf{1 0 0}$ & $\mathbf{1 2 0}$ \\
\hline \multirow{2}{*}{ Grain yield } & RLD & 0.024 & $0.649^{* *}$ & $0.506^{*}$ & $0.584^{*}$ & $0.577^{*}$ \\
& RWD & 0.198 & 0.436 & $0.808^{* *}$ & $0.648^{* *}$ & $0.623^{*}$ \\
\hline \multirow{2}{*}{ WP } & RLD & -0.062 & $0.693^{* *}$ & $0.595^{*}$ & $0.672^{* *}$ & $0.568^{*}$ \\
& RWD & 0.109 & 0.487 & $0.818^{* *}$ & $0.598^{*}$ & $0.562^{*}$ \\
\hline
\end{tabular}

Note: WP, water productivity; RLD, root length density; RWD, root weight density. ${ }^{*}, p<0.05 .{ }^{* *}, p<0.01$.

\section{Discussions}

\subsection{Soil Temperature Responses to the Organic Amendments}

Soil temperature is an important ecological factor for determining water and nutrient uptake by crop root systems [24]. Previous studies have shown the beneficial regulating effects of organic amendments on soil temperature for high soil organic carbon, soil available water content, and soil water holding capacity $[4,25,26]$. Consistent with these findings, MWS reduced the maximum soil temperature and raised the minimum soil temperature, while it significantly reduced the mean soil temperature at $0-10 \mathrm{~cm}$ depth compared to $\mathrm{CO}$ in our study (Figure 2). Hence, the practice of MWS 
can help reduce the adverse effects of terminal heat on the summer maize production in semi-arid regions [27]. By contrast, such beneficial effects did not present themselves in MFM and MBF. Previous studies on organic amendments have also reported that the incorporation of corn straw residue and farmyard manure failed to influence soil temperature $[6,28]$. Inconsistent results obtained here might be related to the type and characteristics of applied organic materials.

\subsection{Soil Water Depletion Responses to the Organic Amendments}

Understanding the process of soil water depletion of a cropping system in a semi-arid region helps maintain a soil hydrological balance and promote crop productivity. Many studies have demonstrated that adding manure and compost increased the available water content and reduced the soil water depletion by improving the soil's physical properties, such as porosity, infiltration, and water retention capacity $[29,30]$. Similarly, organic amendments generally decreased the SWSD in our experiment (Figure 3). The SWSD was significantly low in MBF plots (Figure 3), possibly because the bioorganic fertilizer with living bacteria strongly and rapidly improved the soil's physical environment and thus alleviated soil water stress [13,31]. In addition, MWS and MFM slightly reduced the SWSD compared with CO in 2014, whereas a significant decrease of SWSD under MWS and MFM occurred in 2015 (Figure 3). One probable reason for this may be the accumulative effects of the continuous application of organic materials [3], and another reason may be that nutrient management was more evident during the dry-spell period [20,29].

Furthermore, we observed that the effects of organic amendments on SWSD were mainly significant in the middle soil layer $(20-60 \mathrm{~cm}$ ) in our study (Figure 3). This phenomenon was partly consistent with previous studies in similar environments $[13,32]$. The likely reason for these effects was that loosened topsoil and good crop-root development affected by adding organic amendments promoted water storage and water extraction in the middle soil layer [19]. However, Wiesmeier et al. [33] observed that the application of organic wastes most strongly impacted soil water content in the topsoil, where organic amendments are mostly mixed by cultivation.

\subsection{Maize Root Responses to the Organic Amendments}

Organic amendments are important soil management practices affecting plant root growth. Previous researches have reported the beneficial roles of earthworm compost, green manuring, and farmyard manure on the penetration and establishment of plant roots [20,23,34]. Consistent with these findings, organic amendments generally exerted a clear improvement on the RLD and RWD of maize relative to $\mathrm{CO}$ in our experiment (Figures 5-7), because both soil temperature and water, being substantially influenced by organic amendments, affected plant root growth [17]. By contrast, Espinosa et al. [35] found that manure incorporation severely impaired the total root biomass of grasses when organic amendments were applied in clay subsoil to overcome nutrient deficiencies.

Not only did the maize produce a greater root system with organic amendments, but different types of amendments also had different effectivity on maize root densities-for example, MWS yielded the highest RWD, but the significantly highest RLD was recorded in MBF (Figures 5-7). This discrepancy may be attributed to two causes. Firstly, MWS exerted more favorable heat and water regulation capacities at the early growth stages (Figures 2 and 4), which were beneficial for primary roots' development (Figure 7). Normally, a more vigorous rooting system developed at the early growth stages can give the crop a better chance to survive and grow in semi-arid environments [17], which could lead to the highest RWD in the ensuing growth stages. Secondly, the high decomposition and mineralization turnover under MBF [36] could increase the supply of readily-available nutrients [19] and ultimately promote the development of 'finer' roots [21,23] relative to the other treatments, especially in the deeper layers (Figures 5 and 6). However, the related mechanisms still need to be explored in further studies. 


\subsection{Grain Yield and WP Responses to the Organic Amendments}

Organic amendments had significantly beneficial effects on maize grain yield and WP over two growing seasons (Table 4), and similar findings have also been obtained in other crop species $[8,11,20]$. It is likely that organic amendments generally promote optimum root physiological function [20], which is favorable for the efficient utilization of soil water and nutrients [9,37] for higher yield and WP. Indeed, our results also demonstrated that grain yield and WP had significantly positive correlations with root densities from the middle of the growing seasons onwards (Table 5). Conversely, Yang et al. [1] found that the high $\mathrm{C} / \mathrm{N}$ ratio of organic manure was responsible for its slightly negative effect on crop production in a wheat-soybean cropping system in loess soil, while Edmeades [38] found no significant influence of manure on crop production, with adequate fertilization in all plots.

With regard to the type of organic amendments, the maize grain yield and WP were higher under MWS and MBF than under MFM in both years (Table 4), presumably because they resulted in the closest optimum soil temperatures and water depletion process for promoting greater root density and ultimately boosting higher yield and WP (Figure 8) [10,20]. Interestingly, yield and WP were clearly higher in 2015 (Table 4) with lower cumulative rainfall (Figure 1) than in 2014, which might be attributed to the closer optimal rainfall distribution in 2015 [39].

\section{Conclusions}

Organic amendments resulted in a significant improvement in grain yield and WP of summer maize. Most importantly, MWS and MBF gained significantly higher values compared to MFM. The advantages under MWS and MBF were attributed not only to the optimized soil temperature in the top $10 \mathrm{~cm}$ layer and water depletion in the middle soil layer, but also to the improved root density. Overall, both MWS and MBF could be viable management practices used to alleviate production risks in maize agriculture in semi-arid regions. However, further research in this area is needed, including detailed analyses on the balance between crop nutrient requirements and the chemical composition of organic materials, focusing on long-term effects for relevant soil and crop parameters for sustainable agriculture.

Author Contributions: L.-L.Z. and H.-J.C. conceived and designed the experiments; L.-L.Z., L.-S.L. and X.-H.S. performed the experiments; L.-L.Z., L.-S.L., H.-J.C., X.-H.S. and C.Z. contributed reagents/materials/analysis tools; L.-L.Z. and L.-S.L. analyzed the data; L.-L.Z. wrote the paper; L.-S.L. and H.-J.C. revised the paper.

Funding: This work was supported by the National Key Research and Development Program of China [grant no. 2016YFC0400201] and 111 Project [grant no. B12007].

Acknowledgments: The authors thank Junliang Fan, Shaoping Xue and Jian Wang for their valuable assistance in the experimental work.

Conflicts of Interest: The authors declare no conflict interests.

\section{References}

1. Yang, X.Y.; Li, P.R.; Zhang, S.L.; Sun, B.H.; Chen, X.P. Long-term-fertilization effects on soil organic carbon, physical properties, and wheat yield of a loess soil. J. Plant Nutr. Soil Sci. 2011, 174, 775-784. [CrossRef]

2. Zhang, Y.L.; Li, C.H.; Wang, Y.W.; Hu, Y.M.; Christie, P.; Zhang, J.L.; Li, X.L. Maize yield and soil fertility with combined use of compost and inorganic fertilizers on a calcareous soil on the North China Plain. Soil Tillage Res. 2016, 155, 85-94. [CrossRef]

3. Kowaljow, E.; Gonzalez-Polo, M.; Mazzarino, M.J. Understanding compost effects on water availability in a degraded sandy soil of Patagonia. Environ. Earth Sci. 2017, 76, 255. [CrossRef]

4. Yang, B.J.; Huang, G.Q.; Qian, H.Y. Effects of straw incorporation plus chemical fertilizer on soil temperature, root micro-organisms and enzyme activities. Acta Pedol. Sin. 2014, 51, 150-157. (In Chinese) [CrossRef]

5. Yazdanpanah, N.; Mahmoodabadi, M.; Cerdà, A. The impact of organic amendments on soil hydrology, structure and microbial respiration in semiarid lands. Geoderma 2016, 266, 58-65. [CrossRef] 
6. Lai, R.; Arca, P.; Lagomarsino, A.; Cappai, C.; Seddaiu, G.; Demurtas, C.E.; Roggero, P.P. Manure fertilization increases soil respiration and creates a negative carbon budget in a Mediterranean maize (Zea mays L.)-based cropping system. Catena 2017, 151, 202-212. [CrossRef]

7. Yu, K.; Dong, Q.G.; Chen, H.X.; Feng, H.; Zhao, Y.; Si, B.C.; Li, Y.; Hopkins, D.W. Incorporation of pre-treated straw improves soil aggregate stability and increases crop productivity. Agron. J. 2017, 109, 2253-2265. [CrossRef]

8. Li, S.; Li, Y.B.; Li, X.S.; Tian, X.H.; Zhao, A.Q.; Wang, S.J.; Wang, S.X.; Shi, J.L. Effect of straw management on carbon sequestration and grain production in a maize-Wheat cropping system in Anthrosol of the Guanzhong Plain. Soil Tillage Res. 2016, 157, 43-51. [CrossRef]

9. Das, A.; Patelb, D.P.; Kumara, M.; Ramkrushnaa, G.I.; Mukherjeec, A.; Layeka, J.; Ngachana, S.V.; Buragohain, J. Impact of seven years of organic farming on soil and produce quality and crop yields in eastern Himalayas, India. Agric. Ecosyst. Environ. 2017, 236, 142-153. [CrossRef]

10. Zhang, P.; Wei, T.; Jia, Z.K.; Han, Q.F.; Ren, X.L. Soil aggregate and crop yield changes with different rates of straw incorporation in semiarid areas of Northwest China. Geoderma 2014, 230-231, 41-49. [CrossRef]

11. Agegnehu, G.; Nelson, P.N.; Bird, M.I. Crop yield, plant nutrient uptake and soil physicochemical properties under organic soil amendments and nitrogen fertilization on Nitisols. Soil Tillage Res. 2016, 543, 295-306. [CrossRef]

12. Zheng, J.; Fan, J.L.; Zhang, F.C.; Yan, S.C.; Xiang, Y.Z. Rainfall partitioning into throughfall, stemflow and interception loss by maize canopy on the semi-arid Loess Plateau of China. Agric. Water Manag. 2018, 195, 25-36. [CrossRef]

13. Wang, X.L.; Ren, Y.Y.; Zhang, S.Q.; Chen, Y.L.; Wang, N. Applications of organic manure increased maize (Zea mays L.) yield and water productivity in a semi-arid region. Agric. Water Manag. 2017, 187, 88-98. [CrossRef]

14. Barzegar, A.R.; Yousefi, A.; Daryashenas, A. The effect of addition of different amounts and types of organic materials on soil physical properties and yield of wheat. Plant Soil 2002, 247, 295-301. [CrossRef]

15. Hossain, M.Z.; Niemsdorff, P.V.F.U.; Heß, J. Effect of different organic wastes on soil properties and plant growth and yield: A review. Environ. Sci. 2017, 48, 224-237. [CrossRef]

16. Liu, Z.; Zhu, K.L.; Dong, S.T.; Liu, P.; Zhao, B.; Zhang, J.W. Effects of integrated agronomic practices management on root growth and development of summer maize. Eur. J. Agron. 2017, 84, 140-151. [CrossRef]

17. Guan, D.H.; Zhang, Y.S.; Al-Kaisi, M.M.; Wang, Q.Y.; Zhang, M.C.; Li, Z.H. Tillage practices effect on root distribution and water use efficiency of winter wheat under rain-fed condition in the North China Plain. Soil Tillage Res. 2015, 146, 286-295. [CrossRef]

18. Chilundo, M.; Joel, A.; Wesström, I.; Brito, R.; Messing, I. Response of maize root growth to irrigation and nitrogen management strategies in semi-arid loamy sandy soil. Field Crop. Res. 2017, 200, 143-162. [CrossRef]

19. Gill, J.S.; Sale, P.W.G.; Peries, R.R.; Tang, C. Changes in soil physical properties and crop root growth in dense sodic subsoil following incorporation of organic amendments. Field Crop. Res. 2009, 114, 137-146. [CrossRef]

20. Bandyopadhyay, K.K.; Misra, A.K.; Ghosh, P.K.; Hati, K.M. Effect of integrated use of farmyard manure and chemical fertilizers on soil physical properties and productivity of soybean. Soil Tillage Res. 2010, 110, 115-125. [CrossRef]

21. Zhang, X.Y.; Cao, Y.N.; Tian, Y.Q.; Li, J.S. Short-term compost application increases rhizosphere soil carbon mineralization and stimulates root growth in long-term continuously cropped cucumber. Sci. Hortic. 2014, 175, 269-277. [CrossRef]

22. Mandal, U.K.; Singh, G.; Victor, U.S.; Sharma, K.L. Green manuring: Its effect on soil properties and crop growth under rice-wheat cropping system. Eur. J. Agron. 2003, 19, 225-237. [CrossRef]

23. Gaiottia, F.; Marcuzzoa, P.; Belfiorea, N.; Lovata, L.; Fornasierb, F.; Tomasia, D. Influence of compost addition on soil properties, root growth and vine performances of Vitis vinifera cv Cabernet sauvignon. Sci. Hortic. 2017, 225, 88-95. [CrossRef]

24. Yang, H.S.; Feng, J.X.; Zhai, S.L.; Dai, Y.J.; Xu, M.M.; Wu, J.S.; Shen, M.X.; Bian, X.M.; Koidec, R.T.; Liu, J. Long-term ditch-buried straw return alters soil water potential, temperature, and microbial communities in a rice-wheat rotation system. Soil Tillage Res. 2016, 163, 21-31. [CrossRef] 
25. Mahanta, D.; Bhattacharyya, R.; Gopinath, K.A.; Tuti, M.D.; Jeevanandan, K.; Chandrashekara, C.; Arunkumar, R.; Mina, B.L.; Pandey, B.M.; Mishra, P.K.; et al. Influence of farmyard manure application and mineral fertilization on yield sustainability, carbon sequestration potential and soil property of gardenpea-french bean cropping system in the Indian Himalayas. Sci. Hortic. 2013, 164, 414-427. [CrossRef]

26. Zhang, S.L.; Wang, Y.; Shen, Q.S. Influence of straw amendment on soil physicochemical properties and crop yield on a consecutive mollisol slope in Northeastern China. Water 2018, 10, 559. [CrossRef]

27. Singh, V.K.; Singh, Y.; Dwivedi, B.S.; Singh, S.K.; Majumdar, K.; Jat, M.L.; Mishra, R.P.; Rani, M. Soil physical properties, yield trends and economics after five years of conservation agriculture based rice-maize system in North-Western India. Soil Tillage Res. 2015, 155, 133-148. [CrossRef]

28. Song, Z.W.; Gao, H.J.; Zhu, P.; Chang, P.; Deng, A.X.; Zheng, C.Y.; Mannaf, M.A.; Islam, M.N.; Zhang, W.J. Organic amendments increase corn yield by enhancing soil resilience to climate change. Crop J. 2015, 3, 110-117. [CrossRef]

29. Wang, X.J.; Jia, Z.K.; Liang, L.Y. Effect of straw incorporation on soil moisture, evapotranspiration, and rainfall-use effciency of maize under dryland farming. J. Soil Water Conserv. 2014, 69, 449-455. [CrossRef]

30. Ramos, M.C. Effects of compost amendment on the available soil water and grape yield in vineyards planted after land levelling. Agric. Water Manag. 2017, 191, 67-76. [CrossRef]

31. Eldardiry, E.; Hellal, F.; Mansour, H.; Elhady, M.A. Assessment cultivated period and farm yard manure addition on some soil properties, nutrient content and wheat yield under sprinkler irrigation system. Agric. Sci. 2013, 4, 14-22. [CrossRef]

32. Liu, C.A.; Li, F.R.; Zhou, L.M.; Zhang, R.H.; Jia, Y.; Lin, S.L.; Wang, L.J.; Siddique, K.H.M.; Li, F.M. Effect of organic manure and fertilizer on soil water and crop yields in newly-built terraces with loess soils in a semi-arid environment. Agric. Water Manag. 2013, 117, 123-132. [CrossRef]

33. Wiesmeier, M.; Spörlein, P.; Geuß, U.; Hangen, E.; Haug, S.; Reischl, A.; Schilling, B.; Lützow, M.; Kögel, K.I. Soil organic carbon stocks in Southeast Germany (Bavaria) as affected by land use, soil type and sampling depth. Glob. Chang. Biol. 2012, 18, 2233-2245. [CrossRef]

34. Canellas, L.P.; Olivares, F.L.; Okorokova-Façanha, A.L.; Façanha, A.R. Humic acids isolated from earthworm compost enhance root elongation, lateral root emergence, and plasma membrane $\mathrm{H}^{+}$-ATPase activity in maize roots. Plant Physiol. 2002, 130, 1951-1957. [CrossRef] [PubMed]

35. Espinosa, D.; Peter, W.G.S.; Tang, C.X. Changes in pasture root growth and transpiration efficiency following the incorporation of organic manures into a clay subsoil. Plant Soil 2011, 348, 329-343. [CrossRef]

36. Khaliq, A.; Abbasi, M.K. Improvements in the physical and chemical characteristics of degraded soils supplemented with organic-inorganic amendments in the Himalayan region of Kashmir, Pakistan. Catena 2015, 126, 209-219. [CrossRef]

37. Meade, G.; Lalor, S.T.J.; Cabe, T.M. An evaluation of the combined usage of separated liquid pig manure and inorganic fertiliser in nutrient programmes for winter wheat production. Eur. J. Agron. 2011, 34, 62-70. [CrossRef]

38. Edmeades, D.C. The long-term effects of manures and fertilisers on soil productivity and quality: A review. Nutr. Cycl. Agroecosys. 2003, 66, 165-180. [CrossRef]

39. Wen, Z.H.; Shen, J.B.; Martin, B.; Li, H.G.; Zhao, B.Q.; Yuan, H.M. Combined applications of nitrogen and phosphorus fertilizers with manure increase maize yield and nutrient uptake via stimulating root growth in a long-term experiment. Pedosphere 2016, 26, 62-73. [CrossRef]

(C) 2018 by the authors. Licensee MDPI, Basel, Switzerland. This article is an open access article distributed under the terms and conditions of the Creative Commons Attribution (CC BY) license (http://creativecommons.org/licenses/by/4.0/). 